\title{
Yanık Hastasının Beslenme Gereksinimi: Güncel Öneriler
}

\author{
Sabri KARAHAN", Rana Elçin SEZER CEREN ${ }^{1 *}$, Mesude ÜNSALDI²
}

${ }^{1}$ Hacettepe Üniversitesi Hemşirelik Fakültesi Cerrahi Hastalıkları Hemşireliği, Ankara, Türkiye, ${ }^{2}$ Hannover Medical School, Department of Plastic, Aesthetic, Hand and Reconstructive Surgery Burn Intensive Care, Hannover, Germany

\begin{tabular}{ccc}
\hline Geliş Tarihi & Kabul Tarihi & Yayın Tarihi \\
16.02 .2021 & 27.05 .2021 & 31.12 .2021 \\
\hline
\end{tabular}

Özet: Ölümcül olmayan yanık yaraları dünyada morbiditenin önde gelen nedenleri arasında yer almaktadır. Majör yanıklar vücutta stres tepkisi ile derin metabolik değișime neden olmaktadır. Yanık hastasındaki bu değişimlere yeterli cevap oluşturmak için yanığa özel bazı spesifik beslenme planlamalarına ihtiyaç vardır. İyi bir beslenme planı anabolik metabolizmayı arttırıp, yara iyileşmesini hızlandırmakta ve yanık hastasının hastanede kalış süresini kısaltmaktadır. Etkili bir beslenme planı için alandaki güncel rehberler takip edilmelidir. Bu makalede güncel rehberlerin yanık hastasının beslenmesi konusundaki önerileri derlenmiştir.

Anahtar kelimeler: Beslenme desteği, Güncel Rehberler, Yanık

\section{Nutritional Requirements of Burn Patients: Current Recommendations}

\begin{abstract}
Non-fatal burn wounds are among the leading causes of morbidity in the world. Major burns cause profound metabolic changes with a stress response in the body. In order to create an adequate response to these changes in the burn patient, some specific nutritional planning specific to the burn is needed. A good nutrition plan increases anabolic metabolism, accelerates wound healing and shortens the hospital stay of the burn patient. For an effective nutrition plan, current guidelines in the field should be followed. In this article, recommendations of current guidelines on feeding burn patients were compiled.
\end{abstract}

Keywords: Burn, Current Guidelines, Nutritional Support

\begin{tabular}{llll}
\hline * Sorumlu yazar & Karahan S 0000-0002-0231-3225 & Ceren RES 0000-0001-8579-4660 \\
$\begin{array}{l}\text { Rana Elçin SEZER CEREN } \\
\text { ranaelcin.sezer@gmail.com }\end{array}$ & Ü Ünsaldı M 0000-0003-1581-7200 &
\end{tabular}




\section{GíRiş}

Yanık, tedavisi multidisipliner bir ekip gerektiren ve sürekli bakım ihtiyacı olan karmaşık bir travmadır. Yanıklar termal, kimyasal ve elektirik yanıkları olarak sinıflandırılmakta, termal yanıklar vücudun yoğun ısı teması yoluyla oluşan ve en çok görülen yanık türünü oluşturmaktadır (Peck ve Jeschke, 2011). Amerika Birleşik Devletleri'nde yılda 40.000 kişi yanık nedeniyle hastanelerde yatırllarak tedavi edilmektedir (American Burn Association, 2016). Türkiye'de kesin olmamakla birlikte her yıl 200 bin kişi yanık yaralanmasıyla karşlaşmakta, bunlardan 15 bini hastanelerde yatırılarak tedavi edilmektedir. Türkiye'de ve tüm dünyada önde gelen yaralanmalardan olan yanıkların tedavisi diğer travmalara göre daha uzun sürmekte, ciddi yanıkların tam iyileşmesi aylar hatta yıllar alabilmektedir (Who, 2019).

Yanıklar derinliklerine göre; yüzeyel, kısmi kalınlıkta ve tam kat olarak veya birinci, ikinci ve üçüncü derece yanık olarak derecelendirilmektedir. Birinci derece yanıklarda sadece epidermis etkilenmektedir. İkinci derece yanıklarda epidermis ve dermis etkilenmektedir. Yüzeyel ikinci derece yanıklar sadece papiller dermis tabakasını kapsamakta ve bu yanıklarda büller yaygın olarak görülmektedir. Derin ikinci derece yanıklarda dermisin büyük kısmı zarar görmüştür. Ödem ve yırtılan büller açıkça görülmektedir. Bu tip yanıklar enfeksiyon ve ileriki travmalar ile üçüncü derece yanığa dönüşebilir. Üçüncü derece yanıklarda dermisin tamamen kaybı ve subkütanöz dokuya kadar uzanan bir hasar söz konusudur. Bu yanıklar genellikle kuru, soluk beyaz veya kömür görünümlüdür (Yorgancı ve Geyik, 2007; Hartford ve Kealey, 2012; Brownson ve Gibran, 2018).

Yanıklar ciddiyetine göre majör ve minör yanıklar olarak sinıflandırılmaktadır. $\mathrm{Bu}$ sınıflamada esas alınan değerlendirme ölçütleri; yanı̆̆ın derecesi ve yanık yüzeyinin toplam vücut yüzey alanına (TVYA) oranıdır. Yanık yüzdesi \%25'ten daha büyük ikinci derece ve \%10'dan daha büyük üçüncü derece yanıklar majör yanık olarak değerlendirilir. Yanık yüzdesi $\% 40$ ve daha fazla olan yanıklar ise derecesine bakılmaksızın "ciddi yanık" olarak tanımlanmaktadır (Sağlık Bakanlığı, 2019).

Yanık hastasının metabolik gereksinimleri yanığın genişliğine göre değişiklik göstermektedir. Majör yanıklar vücutta aşırı stres tepkisine neden olarak derin metabolik sorunlara yol açmakta, hastanın enfeksiyona ve hastalığa olan direncini düşürmektedir. Özellikle hipermetabolizma, yara iyileşmesini geciktirmekte, enfeksiyon riskini arttırmakta, mortalite ve morbiditeyi etkilemektedir. $\mathrm{Bu}$ nedenle yanık hastasında, anabolik metabolizmanın arttırılması, stres tepkisinin kontrol altına alınması, ısı kaybınının önlenmesi, sıcak ortam ve yeterli beslenmenin sağlanması gerekir (Greenfield, 2010; Hartford ve Kealey, 2012).

Yanık hastasının tedavi ve bakımında beslenmenin planlanması önemli bir yer tutmaktadır. Beslenmenin planlanmasında, beslenme zamanı, beslenme yolu, kalori ihtiyacının belirlenmesi, enerji açığına göre beslenmenin düzenlenmesi ve beslenme desteği konuları önem kazanmıştır. Birçok önemli rehberde yanık hastasının beslenmesine dair uygulama önerileri yer almaktadır. $\mathrm{Bu}$ derlemede, yanık hastasinın beslenmesinde güncel rehber önerileri ve literatürün değerlendirilmesi amaçlanmaktadır.

\section{Yanıkta metabolik değişimler ve beslenme gereksinimi}

Yanıkta organizmanın tümü etkilenmekte, ortaya çıkan metabolik yanıt diğer travmalara göre daha uzun süreli ve daha yoğun olmaktadır (Durmuş ve ark., 2016). Yanık travması ile cilt bariyerinin bozulması sonucunda protein, mineral, sıvı ve elektrolit kayıpları meydana gelmektedir. Majör yanıklar vücutta stres tepkisi ile derin metabolik değişime neden olmaktadır (Grammatikopoulou ve ark., 2019). Yanık yarasından sonra görülen majör metabolik bozukluklar, artmış katabolik hormonlar (kortizol ve katekolaminler), azalmış anabolik hormonlar (testosteron, büyüme faktörü), vücut sıcaklığında devam eden artış, glikoz ihtiyacında belirgin artış ve hızlı kas yıkımı nedeniyle meydana gelmektedir. Özellikle yara iyileşmesi aşamasında metabolizma yüksek düzeyde enerji 
harcamakta ve bu enerji açığı yanık hastası için uzun süren iyileșme dönemi boyunca devam etmektedir (Şekil 1) ( Aydogan ve Ekici, 2012; Christina ve ark., 2017; Clark ve ark., 2017; Moreira ve ark., 2018).

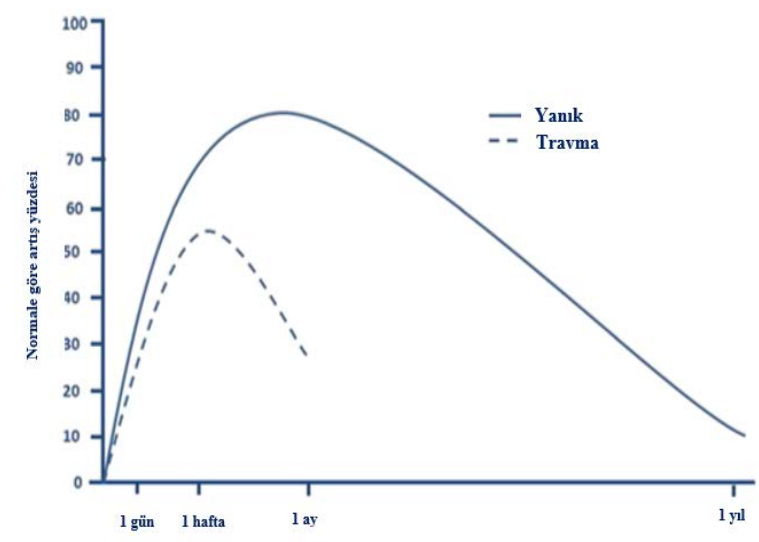

Şekil 1: Yanıkta metabolizma değişimi

Yanık travmasında ortaya çıkan patofizyoloji, endokrin, enflamatuar, metabolik ve immün değişiklikler yanığa özel bazı spesifik beslenme müdahalelerine gereksinimi ortaya çlkarmaktadır (Rousseau ve ark., 2013). Bu müdahalelerin temel amacl protein katabolizmasının ve kas kaybının düzeltilmesi, yara iyileşmesinin desteklenmesi ve bozulan hücre zarı homeostazisi için gerekli mikrobesinlerin sağlanmasıdır (Grammatikopoulou ve ark., 2019). Böylece yanık nedeniyle ortaya çıkan stres tepkisi ve hipermetabolizma durumu azalacak ve artan enerji ihtiyacı karşılanacaktır. $\mathrm{Bu}$ nedenle yanıklı hastalarda beslenme durumunu değerlendirmek ve uygun beslenme planını oluşturmak yanık travmasına bağlı ortaya çıkabilecek komplikasyonların önlemesinde önemlidir (Prelack ve ark., 2007; Prins, 2009; Sobotka, 2017).

\section{Yanık hastasının beslenmesinin planlanması}

Yanık sonrası görülen hipermetabolizma ve stres tepkisinin etkilerini azaltmak ve erken iyileşmeyi sağlamak için etkili bir beslenme planı gereklidir. Yanı hastasının beslenme planlaması, hastanın hastaneye kabulünden itibaren tedavi ve bakımın tüm aşamalarında multidisipliner ekip ile sürdürülmelidir
(Rousseau ve ark., 2013). Avrupa Klinik Nütrisyon ve Metabolizma Derneği (ESPEN) enteral nütrisyon rehberinde ekipteki her sağlık profesyonelinin, kendi uzmanlık alanlarına göre tedavi ve bakımın farklı aşamalarında görev ve sorumluluklarını yerine getirmesinin gerekliliğini belirtmiştir. $\mathrm{Bu}$ bağlamda yanık hastasının beslenme planlaması; beslenmenin değerlendirilmesi, enerji ihtiyacının belirlenmesi ve uygun yol ile beslenme desteğinin sağlanmasını kapsamaktadır (Howard ve ark., 2006; Dimaria-Ghalili ve ark., 2016; Sivrikaya ve Eryılmaz, 2018; Boeykens ve Van Hecke, 2018). Bu planlamaların yapılabilmesi için alana özgü oluşturulan rehberlerin takip edilmesi gerekmektedir. Yanık bakımında güncel olarak kullanılan rehberler; American Burn Association (ABA), European Burn Association (EBA), European Society for Parenteral and Enteral Nutrition (ESPEN), Society for Critical Care Medicine (SCCM), American Society for Parenteral and Enteral Nutrition (ASPEN), International Society for Burn Injury (ISBI) ve Midlands National Health Service (NHS)'dir (Beerthuizen ve Magnette, 2013; Rousseau ve ark., 2013; NHS, 2015; Ahuja ve ark., 2016; Taylor ve ark., 2016; Young ve ark., 2017; Mehta ve ark., 2017).

Tablo 1 ve Tablo 2'de yanık hastasının beslenme planlamasına yönelik rehberlerin önerileri yer almaktadır. Rehberlerde özellikle yanık hastasının hastaneye kabulü ile nütrisyonel taramanın yapılması ve rutin değerlendirmelerin devam etmesi önerilmektedir. Yanık hastasının beslenme zamanının planlaması da rehberlerde özellikle yer alan bir öneridir ve erken zamanda beslenme güçlü kanıt düzeyinde önerilmektedir (Rousseau ve ark., 2013; Beerthuizen ve Magnette, 2013; Ahuja ve ark., 2016; Nhs, 2015; Taylor ve ark., 2016; Mehta ve ark., 2017; Young ve ark., 2017).

Yanık ile vücuttan aşırı miktarda kaybolan sıvının yerine konması ile hidrasyonun sürdürülmesi için sıvı açığının hesaplanması gerekmektedir (Beerthuizen ve Magnette, 2013; Boeykens ve Van Hecke, 2018; Ahuja ve ark., 2016). Büyük yanıklarda yanıklardan sonra ilk iki saatte toplam vücut sıvısının $\% 15$ 'i, ilk sekiz 
saatte \%80'i kaybedilir. Geniş yanıklarda sıvı kayıpları ve ödem hipovolemiye neden olacağından TVYA erişkinlerde $\% 15$, çocuklarda $\% 10$ ve üzeri olan yanıklarda sıvı tedavisine hemen başlanmalıdır. Sıvı tedavinde amaç ekstrasellüler alana geçmiş olan sıvının yerine konulmasıdır (Yorgancı ve Geyik, 2007; Sağlık Bakanlığı, 2019). Hastalara verilecek sıvı miktarını belirlemek için birçok formül kullanılmakta ancak en yaygın kullanılan formül Parkland formülüdür (24 Saatlik Toplam Sıvı İhtiyacı $=4 \mathrm{ml} \times$ TVYA $\times \mathrm{Kg}$ ). Sıvı tedavisi için hesaplanan sivinın 1/2'si ilk 8 saatte, geri kalan sivinın 1/2'si ikinci 8 saatte ve son kalan miktar da üçüncü 8 saatte verilmelidir. Sıvı tedavisinde en sık kullanılan kristalloid Ringer Laktat'tır.
Ringer Laktat yerine \%0,9'luk $\mathrm{NaCl}$ çözeltileri de kullanılabilir. Yanık hastasına sıvı verilmesi için geniş lümenli intravenöz kateter ve idrar çıkışının kontrolü için üriner kateter takılır. Renal perfüzyonunun göstergesi olarak idrar çıkışı dikkatle izlenmeli ve hastanın saatlik idrar çıkışı kaydedilmelidir. Saatlik idrar çıkışı 0,5 $\mathrm{ml} / \mathrm{saat} / \mathrm{kg}$ olması sivı resusitasyonunun yeterliliğini gösterir (Yorgancı ve Geyik, 2007; Beerthuizen ve Magnette, 2013; Sağlık Bakanlığı, 2019). Hastanın idrarı renk açısından da gözlenmelidir. Yanık hastalarda ayrıca böbrek yetmezliği, kalp yetmezliği gibi sistemik sorunların varlığı sıvı resüsitasyonun dikkatle planlanmasını gerektirmektedir (Yorgancı ve Geyik, 2007; Sağlık Bakanlığı 2019).

Tablo 1: Yanık Hastasında Beslenmenin Planlanmasına Yönelik Rehber Önerileri

\begin{tabular}{|c|c|c|c|c|c|c|c|}
\hline Öneri & $\mathrm{ABA}^{1}$ & $\mathrm{EBA}^{2}$ & ESPEN $^{3}$ & $\mathrm{ISBI}^{4}$ & SCCM $^{5}$ & ASPEN6 & $\mathrm{NHS}^{7}$ \\
\hline Hastaneye kabulde nütrisyonel taramanın yapılması & - & - & - & $\sqrt{ }$ & $\sqrt{ }$ & $\sqrt{ }$ & $\sqrt{ }$ \\
\hline Rutin taramaların yapılması & - & $\sqrt{ }$ & - & $\sqrt{ }$ & - & - & $\sqrt{ }$ \\
\hline Hasta için nütrisyonel eğitim & - & $\sqrt{ }$ & - & - & - & - & - \\
\hline Sıvı ihtiyacının belirlenmesi & - & $\sqrt{ }$ & $\sqrt{ }$ & $\sqrt{ }$ & - & - & - \\
\hline Beslenme zamanının planlanması & - & - & $\sqrt{ }$ & $\sqrt{ }$ & $\sqrt{ }$ & $\sqrt{ }$ & $\sqrt{ }$ \\
\hline İndirekt kalorimetri hesabının yapılması & - & - & $\sqrt{ }$ & - & $\sqrt{ }$ & $\sqrt{ }$ & - \\
\hline Hastaya özel enerji gereksiniminin belirlenmesi & $\sqrt{ }$ & $\sqrt{ }$ & $\sqrt{ }$ & $\sqrt{ }$ & $\sqrt{ }$ & $\sqrt{ }$ & $\sqrt{ }$ \\
\hline Hedef protein dozunun belirlenmesi & $\sqrt{ }$ & - & $\sqrt{ }$ & $\sqrt{ }$ & $\sqrt{ }$ & $\sqrt{ }$ & $\sqrt{ }$ \\
\hline Hedef karbonhidrat dozunun belirlenmesi & - & - & $\sqrt{ }$ & - & - & - & - \\
\hline Hedef lipit dozunun belirlenmesi & - & - & $\sqrt{ }$ & - & - & - & - \\
\hline Vitamin C takviyesi & - & - & $\sqrt{ }$ & - & - & - & $\sqrt{ }$ \\
\hline Vitamin D takviyesi & - & - & $\sqrt{ }$ & - & - & - & $\sqrt{ }$ \\
\hline Vitamin E takviyesi & - & - & $\sqrt{ }$ & - & - & - & - \\
\hline Vitamin A takviyesi & - & - & & - & - & - & $\sqrt{ }$ \\
\hline Bakır, selenyum ve çinko desteği & - & - & $\sqrt{ }$ & - & - & - & $\sqrt{ }$ \\
\hline
\end{tabular}

${ }^{1}$ American Burn Association, ${ }^{2}$ European Burn Association, ${ }^{3}$ European Society for Parenteral and Enteral Nutrition, ${ }^{4}$ International Society for Burn Injury, ${ }^{5}$ Society for Critical Care Medicine, ${ }^{6}$ American Society for Parenteral and Enteral Nutrition, ${ }^{7}$ National Health Service

Tablo 2: Beslenme Planına Yönelik Kanıt Düzeyleri

\begin{tabular}{|c|c|c|c|}
\hline Konu & Öneri & Düzey & Öneri Gücü \\
\hline Beslenme zamanı & Beslenme desteğine en erken yanık sonrası 12 saat içinde bașlanmalıdır. & B & Güçlü \\
\hline Beslenme türü & $\begin{array}{l}\text { Beslenme, enteral yolla sürdürülmeli, parenteral beslenme nadiren } \\
\text { düşünülmelidir. }\end{array}$ & $\mathrm{C}$ & Güçlü \\
\hline Enerji gereksinimi & $\begin{array}{l}\text { Enerji gereksinimlerini değerlendirmede indirekt kalorimetre altın } \\
\text { standart olarak düşünülmelidir. İndirekt kalorimetre hesabı uygun } \\
\text { değilse, yetişkinler için Toronto denklemi kullanılmalı, çocuklar için } \\
\text { Schoffield formülü kullanılmalıdır. }\end{array}$ & $\mathrm{D}$ & Zayıf \\
\hline Protein & $\begin{array}{l}\text { Protein gereksinimi yetişkinlerde } 1.5-2 . \mathrm{g} / \mathrm{kg} \text { ve çocuklarda } 1.5-3 \mathrm{~g} / \mathrm{kg} / \\
\text { gün olarak hesaplanmalıdır. Suplement oarak glutamin kullanılmalı, } \\
\text { arjinin kullanılmamalıdır. }\end{array}$ & $\mathrm{D}$ & Güçlü \\
\hline $\begin{array}{l}\text { Glukoz ve glisemik } \\
\text { kontrol }\end{array}$ & $\begin{array}{l}\text { Karbonhidrat alımı yetişkinlerde ve çocuklarda } 5 \mathrm{mg} / \mathrm{kg} / \mathrm{dk} \\
\text { geçmemelidir. Sürekli intravenöz insülin infüzyonu ile glikoz seviyesi } \\
\text { 8mmol/l'nin altında (ve 4,5 mmol / l'nin üzerinde) tutulmalıdır. }\end{array}$ & $\mathrm{D}$ & Güçlü \\
\hline Lipit & Toplam enerjinin \%35'ini așmamalıdır & $\mathrm{C}$ & Zayıf \\
\hline Mikrobesinler & $\begin{array}{l}\text { Yetişkinlerde ve çocuklarda çinko, bakır ve selenyumun yanı sıra B1, C, } \\
\text { D ve E vitamini desteği sağlanmalıdır. }\end{array}$ & $\mathrm{C}$ & Güçlü \\
\hline $\begin{array}{l}\text { Metabolik } \\
\text { modülasyon }\end{array}$ & $\begin{array}{l}\text { Yetişkinlerde ve çocuklarda hipermetabolizmayı azaltmak için beslenme } \\
\text { desteğine ek olarak sıcak bir çevre sağlanmalı, erken eksizyon cerrahisi } \\
\text { yapılmalı, seçici olmayan beta blokerler ve oksandrolon kullanılmalıdır. }\end{array}$ & $\mathrm{D}$ & Zaylf \\
\hline
\end{tabular}


Yanık sonrası iyileşme aylar hatta yıllar sürebilmekte ve yanık yarası taburculuk sonrası dinamik değişimlere açık olabilmektedir. $\mathrm{Bu}$ nedenle taburculuk sonrası hastanın beslenmesinin desteklenmesi ve sürdürülmesi yara iyileşmesi için gereklidir. Rehberler de bu amaçla yanık hastasının eğitimi de özellikle önerilmektedir (Beerthuizen ve Magnette, 2013).

\section{Beslenmenin değerlendirilmesi}

Güncel rehberlerde yanık hastasının beslenme durumunun değerlendirilmesi önerilmektedir (Tablo 1). Yanık hastasina uygun beslenme desteğinin sağlanabilmesi için nütrisyonel risk, hastaneye yatış sırasında ve sonrasında rutin olarak değerlendirilmelidir. Bu değerlendirmeler yanık ekibi ve klinik beslenme ekibinin iş birliği ile hemşire ve diyetisyen tarafından tarama araçları kullanılarak yapılmaktadır (Prelack ve ark., 2007; Rousseau ve ark., 2013). Nütrisyonel riski belirlemeye yönelik rehberler tarafından önerilen pek çok tarama aracı vardır. Nütrisyonel riski değerlendirmede kullanılması önerilen tarama araçları; Nütrisyonel Risk Taraması (NRS 2002-Nutrition Risk Secreening 2002), Malnütrisyon Evrensel Tarama Aracı (MUST-Malnutrition Universal Screening Tool), Kısa Nütrisyonel Değerlendirme Anketi (SNAQShort Nutritional Assessment Questionnaire), Mini Nütrisyonel Değerlendirme (MNA-Mini Nutritional Assessment), Subjektif Global Değerlendirme (SGA-Subjective Global Assessment)'dır. ESPEN bu değerlendirme araçlarının tüm sağlık profesyonelleri tarafından kullanılabileceğini belirtmektedir (Kruizenga ve ark., 2005; Vellas ve ark., 2006; Elia ve ark., 2011; Luzia Valentini ve ark., 2012).

Nütrisyonel Risk Taraması 2002'de hastanın bir, iki ve üç aylık kilo kaybı değeri, yaşı, beslenme durumu, BKİ değeri ve hastalık şiddeti puanlanmaktadır. Hastalar, malnütrisyon riski yok $(<3$ puan) ve malnütrisyon riski var $(\geq 3$ puan) şeklinde sinıflandırılmaktadır (Luzia Valentini ve ark., 2012).

Malnütrisyon Evrensel Tarama Aracı ile hastanın son 6 ayda planlanmamış kilo kaybı, BKİ değeri, akut hastalık skoru her bir parametre 0,1 ya da 2 olacak şekilde puanlandırılmaktadır. Hastalar, malnütrisyon riski düşük risk (0), orta risk (1) ve yüksek risk $(\geq 2)$ şeklinde sinıflandırılmaktadır (Elia ve ark., 2011).

Kısa Nütrisyonel Değerlendirme Anketi ile hastanın son 6 ay içerisinde 6 kg'dan, son 3 ay içerisinde $3 \mathrm{~kg}$ 'dan fazla istemsiz kilo kaybı, iștah azalması ve son 1 ay içerisinde oral ya da tüple beslenme desteği alma durumu puanlandırılmakta, hastaların nütrisyon durumu, iyi beslenmiş ( $<2$ puan), orta malnütrisyon ( 2 puan) ve ağır malnütrisyon ( $\geq 3$ puan) olarak sinıflandırılmaktadır (Kruizenga ve ark., 2005).

SubjektifGlobal Değerlendirme ile hastanın son 6 aydaki toplam kilo kaybi, son 2 haftadaki kilo değişimi, normale göre besin alımındaki değişim, gastrointestinal semptomlar, deri altı yağ doku kaybı, kas güçsüzlüğü, fonksiyonel kapasite, ödem ve asit değerlendirilmekte, multidisipliner ekip ile birlikte kapsamlı bir fizik muayene gerektirmektedir (Bauer ve ark., 2002).

Mini Nütrisyonel Değerlendirme ile hastaların son üç aydaki besin alımlarındaki azalma ve kilo kaybı, mobilite düzeyleri, depresyon ve demans belirtileri, BKİ değeri, akut hastalık şikâyeti, öğün sayısı, gıda ve sıvı alımı, yemek yeme şekli, beslenme konusunda benlik algisı, kol ve baldır çevreleri puanlanmaktadır. Değerlendirmelerde, 17 puan ve aşağısı malnütrisyonu, 17-23,5 arası malnütrisyon riskini ve 24-30 puan arası normal nütrisyonel durum olarak sinıflandırılmaktadır (Vellas ve ark., 2006).

Önerilere göre tarama araçları geçerli ve duyarlı olmalı, eksiksiz, güvenilir bilgi sağlamalı, uygulaması kolay olmalı ve uygulayıcılar arasında farklılık göstermemelidir. Yanıklı hastalarda tarama araçlarının kullanılmadığı durumlarda malnütrisyon tespit edilememekte ve yanığa bağlı ortaya çıkan enflamatuar, metabolik ve immün değişimlere yönelik beslenme desteği sağlanamamaktadır (Türkoğlu ve ark., 2015; Clark ve ark., 2017). Tarama araçlarına ek olarak, beslenmenin değerlendirilmesinde, laboratuvar değerleri (serum albumin, prealbumin, protein, potasyum, hematokrit, kreatinin, hemoglobin vb.) ve aldığıçlkardığı takibine ilişkin veriler de kullanılmalıdır (Prelack ve ark., 2007; Durmuş ve ark., 2016). 


\section{Enerji ihtiyacının belirlenmesi}

Yanık sonrası 72 saat içinde vücudun ihtiyacı olan enerji artarak, 5. ve 7. günlerde en üst noktada olmaktadır. Yanık sonrası vücudun enerji tüketimini etkileyebilecek faktörler arasında yaranın boyutu, cerrahi prosedürler, beslenme desteğinin başlatılması, fizik tedavi, ilaçlar, sepsis ve ortam sıcaklığı yer almaktadır. Ayrıca yanığın şiddeti enerji ihtiyacının belirlenmesinde önemli bir faktördür. Enerji ihtiyacını belirlemek için kullanılan en yaygın iki yöntem, matematiksel formüller ve indirekt kalorimetri hesabıdır (Christina ve ark., 2017; Young ve ark., 2017).

Matematiksel formüllerde vücut ağırlığı ve vücut yüzey alanı temelli formüller (Currreri, Harris Benedict ve kilogram başına kalori hesaplanması vb.) kullanılmaktadır. Fakat bu formüller kişide zamanla gerçekleşen metabolik hızdaki değişimi baz almamakta ve bireyin gerçek enerji ihtiyacını belirleyememektedir. Böylece birey ya gereksiniminden az beslenmekte ya da aşırı beslenme riskine maruz kalmaktadır. İndirekt kalorimetri hesaplaması ise istirahat metabolizma hızının solunum yolu (oksijen tüketimi) ile ölçülmesidir. Enerji gereksiniminin belirlenmesinde altın standart olan bir hesaplamadır. Enerji hesaplamasında İndirekt kalorimetrinin kullanılmadığ Toronto formülü en güvenilir formüllerden birisidir. Cinsiyet, ağırlık, boy, yanık yüzdesi, ateş, önceki gün enerji alımı ve travmadan beri devam eden süre kullanılarak enerji ihtiyacı hesaplanmaktadır (Tablo 3) (Rousseau ve ark., 2013; Durmuş ve ark., 2016; Christina ve ark., 2017; Young ve ark., 2017).

Tablo 3: Yanık hastasının enerji ihtiyacı formülleri

\begin{tabular}{|c|c|}
\hline $\begin{array}{l}\text { Harris Benedict } \\
\text { Formülü }\end{array}$ & $\begin{array}{l}\text { Kadınlar için: } 655,1+(9,56 \text { x kilo })+(1,85 \text { x boy })-(4,68 \text { x yaş }) \text { x Aktivite Faktörü x Hastalık } \\
\text { Faktörü } \\
\text { Erkekler için: } 66,47+(13,75 \times \text { kilo })+(5 \text { x boy })-(6,76 \text { x yaș }) \times \text { Aktivite Faktörü x Hastalık Faktörü }\end{array}$ \\
\hline Curreri Formülü & $(25 \mathrm{x}$ ağırlık $(\mathrm{kg}))+(40 \mathrm{x}$ TVYA $)$ \\
\hline Toronto Formülü & $\begin{array}{l}-4343+(10,5 \times \text { Yanık yüzdesi })+(0,23 \text { x Önceki günkü enerji alımı })+\left(0,84 \times \text { REE}^{*}\right)+\left(114 \times \mathrm{T}^{\circ} \mathrm{C}\right)- \\
(4,5 \mathrm{x} \text { Hasar sonrası gün })\end{array}$ \\
\hline Xie Formülü & $\left(1000 \mathrm{kcal} \times \mathrm{BSA}^{*}\right)+\left(25 \mathrm{x} \% \mathrm{TBSA}^{* *}\right)$ \\
\hline $\begin{array}{l}\text { Kilogram başına } \\
\text { kalori hesabı }\end{array}$ & $\begin{array}{l}\text { Obez ve kritik hasta popülasyonu için: } 21 \mathrm{kcal} / \mathrm{kg} \\
\text { Obez olmayan hasta popülasyonu için: } 25-35 \mathrm{kcal} / \mathrm{kg}\end{array}$ \\
\hline
\end{tabular}

\section{Makro besin öğeleri}

Protein; enerji ihtiyacının belirlenmesi ve sağlanan beslenme desteği ile protein sentezi optimize edilmektedir. İdrarda protein kayıpları, glukoneogenezde protein kullanımı ve yara iyileşme sürecinde protein ihtiyacı yanıklı bir hastanın artmış protein ihtiyacı olduğunu göstermektedir. ASPEN'e göre, kritik hastalar, protein devir hızı, sentez, parçalanma ve oksidasyondaki artışlara bağlı olarak artan bir protein kaybı riski altındadır (Taylor ve ark., 2016). Yanıklı hastalarda günlük 1,5-2 g/kg protein alımı önerilmektedir (Rousseau ve ark., 2013).

Karbonhidratlar; yanık hastalarının beslenmesinde ana enerji kaynağıdır. Ayrıca yanıklı hastanın beslenmesinde yer alan yağlar karbonhidrata ihtiyacı azaltmakta ve glikoz toleransını iyileștirmektedir. Yanık hastalarında karbonhidrat alımının, toplam enerji gereksiniminin \%55 ile \%60'ına denk gelmesi ve sağlıklı birey ile aynı şekilde olması önerilmektedir. Yanık hastalarının enerji ihtiyaçları normalden daha yüksek olduğundan, hiperglisemiye neden olabilecek aşırı karbonhidrat yükünden kaçınmak gerekmektedir. ESPEN yanık hastaları için sıkı glisemik kontrolü ve kan glikoz düzeyinin 81 ile $144 \mathrm{mg} / \mathrm{dL}$ arasında kontrolünü önermektedir (Aydogan ve Ekici, 2012; Rousseau ve ark., 2013). Aşırı karbonhidrat yüklenmesi sıklıkla IV yol tercih edildiği zaman yaşanmaktadır. Yetişkinler için maksimum intravenöz karbonhidrat infüzyon hızı 5 ile $7 \mathrm{mg} / \mathrm{kg} /$ gün olarak önerilmektedir (Christina ve ark., 2017). Yağlar; yağ asidi eksikliği görülmemesi için yanık hastasının diyetinde yağ bulunması önerilmektedir. Fakat yanık travması sonrası 
lipolizis baskılanır ve enerji için yağ asidi kullanımı azalır. Fazla yağ alımı, karaciğerde yağlanmaya neden olması ve immün sistemi olumsuz etkilemesi nedeniyle önerilmemektedir. Yanık hastalarında yă alımına dair güçlü öneri yoktur, normal beslenmede yer alan toplam enerjinin \%35'ini aşmamalıdır (Rousseau ve ark., 2013; Clark ve ark., 2017; Christina ve ark., 2017).

\section{Mikro besin öğeleri}

Yanık travması ile meydana gelen hipermetabolizma, eksüdatif oksidasyon ve inflamuar yanıt sonucu vitamin ve minerallere olan gereksinim artmaktadır. Ayrıca yanık yaralanmasında oluşan reaktif oksijen yara iyileşmesinde ve mortalite riskinde çok önemli olan antioksidan sistemlerinin azalmasına neden olmaktadır. Yara iyileşmesinin stimülüzasyonunda vitamin, mineral ve antioksidanların (A ve $\mathrm{C}$ vit.) kullanımı artmaktadır. Yanma sonrası yeterli yara iyileşmesini desteklemek için, beslenme planlanmasına A vitamini, $C$ vitamini, $E$ vitamini, çinko, bakır, selenyum eklenmesi önerilmektedir (Aydogan ve Ekici, 2012; Rousseau ve ark., 2013).

C vitamini ve $E$ vitamini kullanımının oksidatif stresi azalttığı ve yara iyileşmesine faydalı olduğu gösterilmiştir (Barbosa ve ark., 2009). C vitamini, kollajen oluşumuna ve çapraz bağlanmaya yardımcı olur. Ayrıca ilk 24 saatte çok yüksek dozda C vitamini verilmesi hücre zarının stabilize ederek sıvı resüsitasyonu ihtiyacını azaltabilir (Taylor ve ark., 2016). A vitamini de $\mathrm{C}$ vitamini gibi kollajen sentezine yardımcı olur ve epitelizasyon için gereklidir. Yanık yaralanması D vitamini metabolizmasını hasara uğratır ve 25-hidroksi vitamin D düzeyi azalır. Ciddi yanık sonrası kırık riski nedeniyle, yanık hastaları yeterli miktarda kalsiyum ve D vitamini almalıdır (Aydogan ve Ekici, 2012; Rousseau ve ark., 2013).

Çinko, bakır, selenyum hücresel ve humoral bağışıklık için önemlidir ve yanık yarası sonrası büyük miktarlarda kaybolmaktadır. Çinko yara iyileşmesi, lenfosit fonksiyonu, DNA replikasyonu ve protein sentezi için kritiktir. Bakır, yara iyileşmesi ve kollajen sentezi için gereklidir. Bakır ve selenyum eksikliği, aritmilere ve bağışıklığın azalmasına neden olmaktadır. Bakır, selenyum ve çinko gibi eser elementlerin standarttan daha yüksek bir dozda kullanımı ESPEN tarafından önerilmektedir (Rousseau ve ark., 2013; Clark ve ark., 2017).

\section{Beslenme desteğinin sağlanması}

Rehberler beslenme desteğine en erken yanık sonrası 12 saat içinde başlanmasını önermektedir. Hastanın oral yolu tolere edebildiği durumlarda beslenme doğal yoldan sağlanmalıdır. Oral yolun kullanılamadığı durumlarda beslenme, enteral yolla sürdürülmelidir (Rousseau ve ark., 2013). Enteral beslenme barsak bariyer fonksiyonunu aktive ettiği için ve aminoasitler ile yağların emilimini gerçekleştirdiği için öncelikli tercih edilmesi gereken beslenme yöntemidir (Prelack ve ark., 2007; Luzia Valentini ve ark., 2012). Erken dönemde uygulanan enteral beslenme iç organların perfüzyonunu desteklemekte, yanığa bağlı ortaya çıkan hipermetabolik yanıtı, bakteri translokasyonunu, sepsisi azaltmakta ve bağırsak mukoza bütünlüğünü sağlamaktadır. Enteral beslenmede seçilecek yol hastanın klinik durumuna göre değişiklik göstermektedir (Prelack ve ark., 2007; Sobotka, 2017). Beslenmede nazogastrik yol, nazojejunal yol tercih edilmekle birlikte yüzdeki ağır yanıklarda nazogastrik yol ile beslenmenin sağlanması zor olacağı için perkütan endoskopik gastrostomi (PEG) tercih edilmektedir. Kullanılan ilaçlar ve ağır sedasyon nedeniyle mide boşalmasında gecikme meydana gelen ve aspirasyon pnömonisi riski olan hastalarda beslenme postplorik yol (perkütan endoskopik jejunostomi) ile sürdürülmelidir (Şekil 2) (Prelack ve ark., 2007; Rousseau ve ark., 2013; Sabotka, 2017).

Ticari olarak hazırlanmış birçok enteral beslenme ürünü bulunmaktadır. $\mathrm{Bu}$ ürünler nitrojen, fiber, aminoasit, modifiye yağ ve karbonhidrat içermektedir. Yanık hastalarının eşlik eden başka hastalıkları olabileceği göz önüme alınarak her hasta için ayrı ve hastaya özel beslenme desteği düşünülmelidir (Rousseau ve ark., 2013; Sobotka, 2017; Christina ve ark., 2017). 
Parenteral beslenme ise yanıkta beslenme desteğinde ikinci seçenektir. Yanıkta parenteral beslenme endikasyonları, tolore edilmeyen enteral beslenme, vücut ağırlığının \%10'nunda fazlasının kaybı, klinik duruma bağlı yetersiz beslenme, uzamış yara iyileşme sürecidir. Yanıklı hastalarda parenteral beslenmede santral yol tercih edilmelidir. Periferik yolun kullanımında ise katabolizmayı önleyecek kadar yeterli miktarda enerji desteği sağlanamamaktadır. Parenteral beslenme hastalarda enfeksiyon, sepsis ve mekanik komplikasyonlara eğilimi artırmakta ve parenteral beslenmede kullanılan ürünler, enteral beslenme ürünlerine göre daha maliyetli olmaktadır (Durmuş ve ark., 2016; Juquan ve ark., 2020).

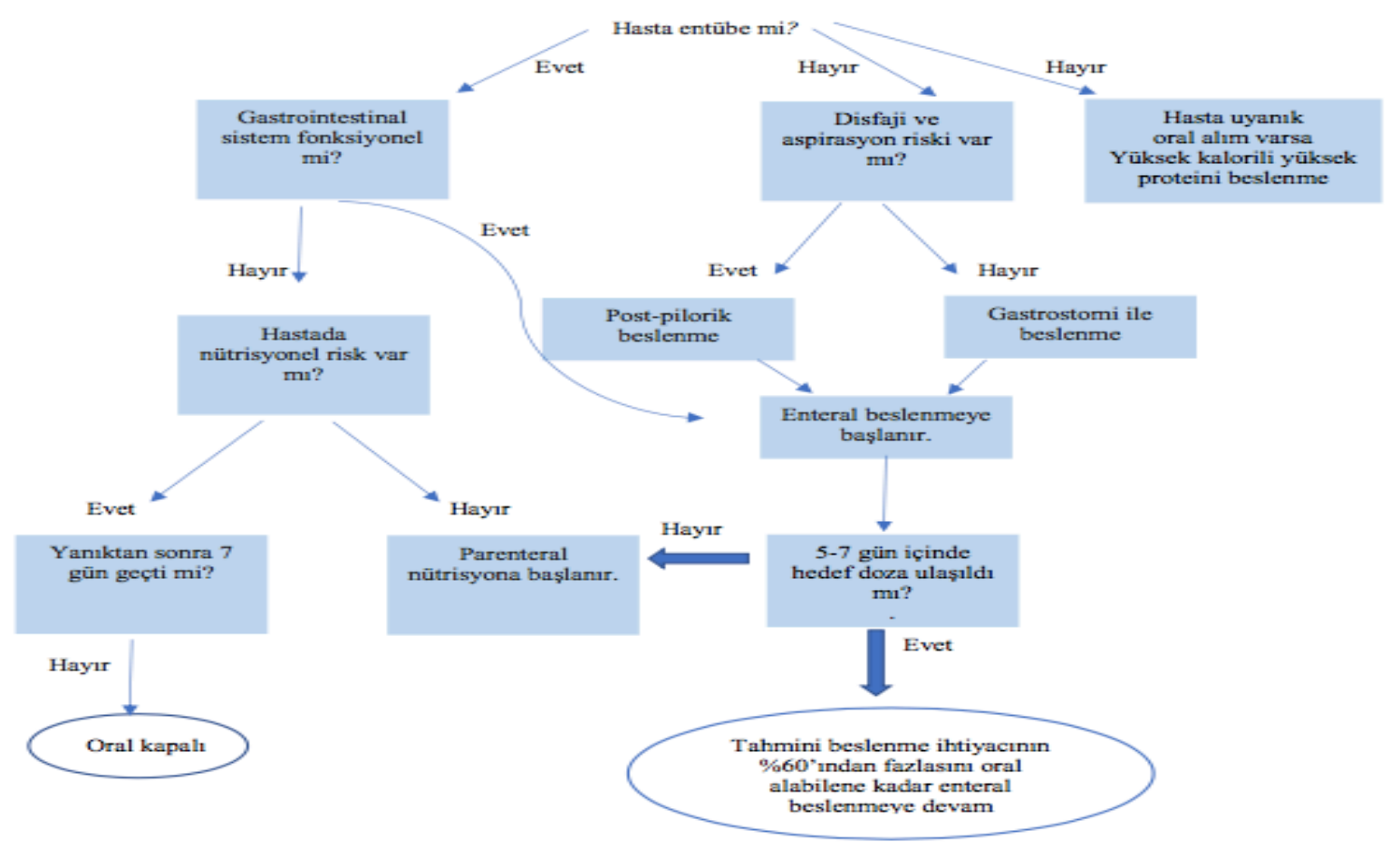

Şekil 2. Yanık hastasında beslenme desteğini uygulama yolu kavram haritası

\section{SONUÇ ve ÖNERILER}

Ciddi yanıklar vücutta derin metabolik sorunlara neden olmaktadır. Buna ek olarak yanık yarasının iyileşmesi sırasında metabolizma yüksek düzeyde enerjiye ihtiyaç duymaktadır. Yanık travması ve iyileşme sürecinde meydana gelen derin metabolik değişimlerle baş etmek yanık hastasının beslenmesini dinamik şekilde düzenlenmesi ile mümkündür. Bu düzenleme, enerji ihtiyacının belirlenmesi, uygun beslenme öğelerinin seçimi, beslenme yolu ve zamanlamasını içerir. Uzun süren iyileşme döneminde yanık hastasının beslenmesinin optimum seviyede sürdürülmesi, yanık yaralarının hızla iyileşmesini, komplikasyonların önlenmesini ve hastanede kalış süresinin kısalmasını sağlar.

Yanık hastasının beslenmesinin planlanması ve sürdürülmesinde güncel kaynaklar kullanılmalı- dır. Bu kaynaklar alana özgü oluşturulan kanıt temelli önerilerin yer verildiği güncel rehberlerdir. Yanık tedavi ve bakımında yer alan sağlık profesyonellerinin güncel rehberlere göre yanık hastasının enerji ihtiyacını sürekli formülasyon ile değerlendirmesi ve hastalara yeterli beslenme desteği sağlaması önerilmektedir.

\section{Çıkar Tartışması Bildirimi}

Makalede isimleri listelenen yazarların makalede sunulan veriler ve/veya makalenin konusu ile ilgili olarak herhangi bir kişi ya da kuruluş ile çıkar ilişkisi yoktur.

\section{KAYNAKLAR}

Ahuja RB, Gibran N, Greenhalgh D, Jeng J, Mackie D, Moghazy A, Moiemen N, Palmieri T, Peck M, \& Serghiou M (2016) ISBI practice guidelines for burn care. Burns, 42, 953-1021. 
American Burn Association (2016) Burn incidence and treatment in the United States [Online] http://www.ameriburn.org/resources_factsheet.php [Erişim Tarihi: 11.09.2020].

Aydogan C, Ekici Y (2012) Yanik Hastalarinda Beslenme/Nutrition Support in Burn Patients. Turk J Intensive Care, 10, 74.

Barbosa E, Faintuch J, Machado Moreira EA, Gonçalves Da Silva VR, Lopes Pereima MJ, Martins Fagundes RL, Filho DW (2009) Supplementation of vitamin $\mathrm{E}$, vitamin $\mathrm{C}$, and zinc attenuates oxidative stress in burned children: a randomized, doubleblind, placebo-controlled pilot study. JBCR, 30, 859866.

Bauer J, Capra S, Ferguson M (2002) Use of the scored Patient-Generated Subjective Global Assessment (PG-SGA) as a nutrition assessment tool in patients with cancer. Eur J Clin Nutr, 56, 779-785.

Beerthuizen G, Magnette A (2013) European practice guidelines for burn care. Vienna.

Boeykens K, Van Hecke A (2018) Advanced practice nursing: Nutrition Nurse Specialist role and function. Clin. Nutr. ESPEN, 26, 72-76.

Brownson EG, Gibran NS (2018) Evaluation of the Burn Wound: Management Decisions. In: HERNDON, D. N. (ed.) Total Burn Care. 5 ed.: Elsevier.

ChristinaR, Franziska H, Michael WN (2017) Clinician's guide to nutritional therapy following major burn injury. Burn Care: Rescue, Resuscitation, and Resurfacing, An Issue of Clinics in Plastic Surgery, E-Book, 44, 555.

Clark A, Imran J, Madni T, Wolf SE (2017) Nutrition and metabolism in burn patients. Burns trauma, 5 .

Dimaria-Ghalili RA, Gilbert $K$, Lord L, Neal T, Richardson $D$, Tyler $R$, Guenter $P$ (2016) Standards of Nutrition Care Practice and Professional Performance for Nutrition Support and Generalist Nurses. Nutrition in clinical practice: official publication of the J Parenter Enteral Nutr. 31, 527.

Durmuş M, Muhsiroğlu Ö, Yapici AK, Bayram Y, Eski M (2016) Yanıkta Tibbi Beslenme Tedavisi. Turk J Plast Surg24.

Elia M, Russell C, Stratton R, Todorovic V, Evans L, Farrer K (2011) The MUST explanatory booklet. A guide to the Malnutrition Universal Screening Tool (MUST) for adults. London: BAPEN.

Grammatikopoulou MG, Theodoridis X, Gkiouras K, Stamouli EM, Mavrantoni ME, Dardavessis T, Bogdanos DP (2019) AGREEing on guidelines for nutrition management of adult severe burn patients. J Parenter Enteral Nutr., 43, 490-496.
Greenfield E (2010) The pivotal role of nursing personnel in burn care. Indian J Plast Surg official publication of the Association of Plastic Surgeons of India, 43, S94.

Hartford CE, Kealey GP (2012) Care of outpatient burns. Total Burn Care. 4th ed. Philadelphia, PA: Saunders, 81e2-92e2.

Howard P, Jonkers-Schuitema C, Furniss L, Kyle U, Muehlebach S, Ödlund-Olin A, Page M, Wheatley C (2006) Managing the patient journey through enteral nutritional care. Clin Nutr, 25, 187-195.

Juquan S, Steven EW, Charles EW, Thomas RZ (2020) Specialized nutrition support in burns, wasting, deconditioning, and hypermetabolic conditions. In: Marriott, B. P., Birt, D. F., Stallings, V. A. \& Yates, A. A. (eds.) Present Knowledge in Nutrition 11 ed.

Kruizenga H, Seidell J, De Vet HC, Wierdsma N (2005) Development and validation of a hospital screening tool for malnutrition: the short nutritional assessment questionnaire (SNAQC). Clin Nutr, 24, 75-82.

Luzia Valentini TS, Simon Allison PH, Lochs CPAH (2012) ESPEN Enteral Nutrisyon Rehberi.

Mehta NM, Skillman HE, Irving SY, Coss-Bu JA, Vermilyea S, Farrington EA, Mckeever L, Hall AM, Goday PS, Braunschweig C (2017) Guidelines for the provision and assessment of nutrition support therapy in the pediatric critically ill patient: Society of Critical Care Medicine and American Society for Parenteral and Enteral Nutrition. J Parenter Enteral Nutr, 41, 706-742.

Moreira E, Burghi G, Manzanares W (2018) Update on metabolism and nutrition therapy in critically ill burned patients. Medicina Intensiva (English Edition), 42, 306-316.

Nhs (2015) Midlands Burn Operational DeliveryNetworkGuidelines for the Nutritional Management of Adults and Paediatrics Midland Burn Operational Delivery Network, 2.

Peck MD, Jeschke M (2011) Epidemiology of burn injuries globally. Burns, 37.

Prelack K, Dylewski M, Sheridan RL (2007) Practical guidelines for nutritional management of burn injury and recovery. Burns, 33, 14-24.

Prins A 2009 Nutritional management of the burn patient. South Afr J Clin Nutr 22, 9-15.

Rousseau AF, Losser MR, Ichai C, Berger MM (2013) ESPEN endorsed recommendations: nutritional therapy in major burns. Clin Nutr, 32, 497502 . 
Sağlık Bakanlığı (2019) Yanık Tedavi Algoritması [Online].

https://khgmsaglikhizmetleridb.saglik.gov.tr/TR-

42844/yanik-tedavi-algoritmasi.html [16.09.2020].

Sivrikaya SK, Eryilmaz A (2018) Nütrisyonel Destek Ekibinde Hemşirelik. Samsun Sağ Bil Der 3, 33-37.

Sobotka L (2017) Klinik nütrisyon temelleri. Çev. ed. Gündoğdu RH. Ankara, Bayt Yayın.

Taylor BE, Mcclave SA, Martindale RG, Warren MM, Johnson DR, Braunschweig C, Mccarthy MS, Davanos E, Rice TW, Cresci G A (2016) Guidelines for the provision and assessment of nutrition support therapy in the adult critically ill patient: Society of Critical Care Medicine (SCCM) and American Society for Parenteral and Enteral Nutrition (ASPEN). Crit. Care Med., 44, 390-438.

Türkoğlu İ, Ilgaz F, Yalçin T, Yürük AA, Aksan A, Çerçi A, Özel HG, Yildiz E, Samur G (2015) Hastanede yatan yetişkin hastalarda malnütrisyon prevelansı: dört farklı beslenme tarama aracının karşılaștırılması. Bes Diy Derg, 43, 135-142.

Vellas B, Villars H, Abellan G, Soto M, Rolland Y, Guigoz Y, Morley J, Chumlea W, Salva A, Rubenstein L (2006) Overview of the MNA®-Its history and challenges. J Nutr Health Aging, 10, 456.

Who (2019) World Health Organization. Burns [Online]. World Health Organization. https://www.who.int/news-room/factsheets/detail/burns [Erişim Tarihi: 11.09.2020].

Yorganci K, Geyik S (2007) Ciddi Yanık Hastasının İzlem ve Tedavisi. Hacettepe Tıp Dergisi, 38, 135-140.

Young AW, Graves C, Kowalske KJ, Perry DA, Ryan CM, Sheridan RL, Valenta A, Conlon KM, Jeng JC, Palmieri T (2017) Guideline for burn care under austere conditions: special care topics. JBCR , 38, e497-e509. 